\section{OBSERVATIONS ON THE USE OF THE CATGUT LIGATURES.}

By E. DOWNES, M.D. BRUSSEls, L.R.C.P. LOND., MEDICAL MISSIONARY OF KASHMIR.

IN THE LANCET of Nov. 19th, 1881, appeared a paper by Dr. French on the above subject. Dr. French, after recording a case of Mr. Barwell's, published in THE LANCET of July 30th, in which hæmorrhage occurred when the uinar artery had been tied, and was attributed by Mr. Barwell to the use of a thick catgut ligature, proceeds to give his own experience, which goes far to prove (if proof is still wanting) that the catgut is the best substance for the ligature of arteries. At the same time, Dr. French had observed secondary hæmorrhage on one or two occasions when he had ligatured vessels on the human subject; and on one occasion when he experimentally tied the femoral artery of a dog. He thinks the hæmorrhage may have been due to using a thick ligature, and advises the use of a thin ligature. $\mathrm{He}$ says : "To those who are in a position to carry out experiments, I venture to suggest the advisability of determining whether, in many cases, the secondary hæmorrhage is not chiefly due to the employment of catgut ligature of too large a size." I determined to undertake some experiments to satisfy myself on this point. I may say that, with some little experience with catgut ligatures in surgical cases, I have never once had a case of secondary hæmorrhage. I ordered ten healthy dogs to be procured, and determined to tie the femoral arteries of these animals. I had procured catgut ligature from Messrs. Weiss of London a year ago. On the bottle they were described as four kinds, the numbers being " 0 , 1 , 2, and 3, as used by Professor Lister." I could only distinguish three kinds ; probably the two smallest kinds were much alike, and, having been well soaked in oil, I really could not distinguish them ; I therefore called the three kinds which I could distinguish large, medium, and small respectively. The dogs were put under chloroform, and the operations were performed with strict antiseptic precautions. One dog died under chloroform, though every precaution was taken. I may mention that I have observed what $I$ have never seen mentioned elsewhere-viz, that dogs and foxes, and probably all animals of this kind, are easily killed by chloroform, far more easily than human beings. So nine dogs only were operated on ; three had their femoral arteries tied with the large, three with the redium, and three with the small catgut ligature. The dogs tore off the dressings from the first day to the third, but some of the wounds healed by first intention; in the other cases the edges of the skin gaped, but there was no suppuration in any case, nor was there any secondary hæmorrhage. I need hardly say that I cut the ends of the ligatures short and closed the wounds with fine catgut sutures. I intended to have killed all these nine dogs three weeks after the operations, but the hospital servants begged for the life of one dog so that he might be kept as a watch dog for the establishment. I consented; so only eight dogs remained to be killed and examined post mortem. The dogs were allowed to live over three weeks. Three had been operated on with large, three with medium, and two with small catgut; the fortunate dog having been operated on with the small.

The result of the post-mortem examinations was as follows :-1. Large ligature ; artery quite blocked; walls of vessel uninjured; no mark left by ligature. 2. Large ligature; artery quite blocked; walls of vessel uninjured; no mark left by ligature. 3. Large ligature; artery nearly blocked, but apparently a small channel open; walls also uninjured. 4. Median ligature; artery quite blocked by a very firm clot; walls quite uninjured. 5. Median ligature ; artery closed by a small clot, but channel impervious; walls of artery uninjured. 6. Median ligature; channel quite open; a little roughening in one place of the inside of the vessel, perhaps the remains of the clot; walls uninjured. 7. Small ligature; walls of artery nearly cut through by ligature, but artery thoroughly blocked above. 8. Small ligature; the most complete obliteration of the artery for the distance of about half an inch; walls quite uninjured. In no case was any trace of the ligature to be found; it had in every instance been completely absorbed.

I should mention that in tying the vessels I used three twists, as recommended by my old instructor Mr. Lane, of
St. Mary's Hospital, instead of the two twists of the ordinary reef knot. It will be observed that this would make the knot still larger than it would have been, and, according to Dr. French and Mr. Barwell, this would increase the danger of secondary hæmorrhage. Notwithstanding this, I did not have secondary hæmorrhage in any case. The only instance in which the wall of the vessel was injured was a case in which the finest ligature was used. I think that with such fine ligature too much force in tying the knot should not be employed. Probably in my case the vessel would not have been injured had I been more careful; but I used as much force as I should have done with a silk ligature when I wished to cut through the inner coat of the artery. My con. clusion is that Dr. French's idea that the small ligatures are safer than the large ones is not correct. I also think that with large ligatures the third twist in the knot is an important precaution. I also feel sure that with large ligatures especially it is most important that thoroughly reliable material should be used. If large ligatures are used moderate force should be employed in tying the knot; but if fine ligatures are used $I$ think it unadvisable to attempt to cut through the inner coat of the vessel.

Kashmir.

ON AN

INFECTIOUS ULCERATIVE DISEASE OF SKIN AND MUCOUS MEMBRANE CAUSED BY A SPECIFIC BACILLUS.

\author{
BY ALFRED LINGARD, M.R.C.S., \\ AND
}

ERNEST E. BATT, M.R.C.V.S.

A DISEASE of the above character having yearly caused considerable ravages among young cattle in this country, portions of the affected organs were received by us at the Brown Institution for examination.

The following are a few points we wish to make known prior to the completion of the research, which is so far ad. vanced that it will shortly be published in full :-The tongue and mucous membrane of the cheeks are the usual localities of the primary lesion. The typical ulcer in advanced cases consists of a sore with free, overhanging edges. On section through the sore, the tongue is found to be necrosed to a considerable depth opposite all parts of the ulcer. Wherever the sore touches any other part of the mouth or cheek, the disease is communicated and rapidly spreads. In some cases similar necrotic changes had taken place in the lungs. The line of junction of the necrotic with the healtby tissues was found to be occupied by a mass of bacilli having the appearance of a dense phalanx advancing upon the healthy tissues. The disease has been proved capable of transmission by the bacilli in question, which are equally numerous and virulent after passing through several generations by inoculation.

\section{2. antirror}

or

\section{HOSPITAL PRACTICE, BRITISH AND FOREIGN.}

Nulla autem est alia pro certo noscendi via, nisi quamplurimas et morborum et dissectionum historias, tum aliornm tum proprias collectas habere, et inter se comparare.-Morga Gar De Sed. et Caus. Morb., lib. iv. Procmium.

\section{UNIVERSITY COLLEGE HOSPITAL.}

FIVE CASES OF SUBCORACOID AND ONE OF SUBGLEYOTD DISLOCATION OF THE HUMERUS REDUCED BY KOCHER'S METHOD.

(Under the care of Mr. C. HEATH.)

For the following notes we are indebted to Mr. W. Chisholm, house-surgeon, who effected the reduction in all the cases except the first.

In The LANCET of Nov. 4th, 1882, p. 773, attention was called to a paper on a method of reducing dislocations of the shoulder, read by $M$. Kocher at the meeting of the 